\title{
S-nitrosylation in the regulation of gene transcription
}

\author{
Yonggang Sha and Harvey E. Marshall \\ Division of Pulmonary, Allergy, and Critical Care Medicine, Department of Medicine, Duke \\ University Medical Center, Durham, North Carolina, USA
}

\begin{abstract}
Background-Post-translational modification of proteins by S-nitrosylation serves as a major mode of signaling in mammalian cells and a growing body of evidence has shown that transcription factors and their activating pathways are primary targets. S-nitrosylation directly modifies a number of transcription factors, including NF- $k$ B, HIF-1, and AP-1. In addition, Snitrosylation can indirectly regulate gene transcription by modulating other cell signaling pathways, in particular JNK kinase and ras.
\end{abstract}

Scope of review-The evolution of S-nitrosylation as a signaling mechanism in the regulation of gene transcription, physiological advantages of protein S-nitrosylation in the control of gene transcription, and discussion of the many transcriptional proteins modulated by S-nitrosylation is summarized.

Major conclusions-S-nitrosylation plays a crucial role in the control of mammalian gene transcription with numerous transcription factors regulated by this modification. Many of these proteins serve as immunomodulators, and inducible nitric oxide synthase (iNOS) is regarded as a principal mediatiator of NO-dependent S-nitrosylation. However, additional targets within the nucleus (e.g. histone deacetylases) and alternative mechanisms of S-nitrosylation (e.g. GAPDHmediated trans-nitrosylation) are thought to play a role in NOS-dependent transcriptional regulation.

General significance-Derangement of SNO-regulated gene transcription is an important factor in a variety of pathological conditions including neoplasia and sepsis. A better understanding of protein S-nitrosylation as it relates to gene transcription and the physiological mechanisms behind this process is likely to lead to novel therapies for these disorders. This article is part of a Special Issue entitled Regulation of Cellular Processes by S-nitrosylation.

\section{Keywords}

S-nitrosylation; Nitric oxide; Gene transcription; Transcription factors

\footnotetext{
This article is part of a Special Issue entitled Regulation of Cellular Processes by S-nitrosylation. (C) 2011 Published by Elsevier B.V.

*Corresponding author at: MSRB 201, Box 2613, Duke University Medical Center, Durham, NC 27710, USA. marsh015@mc.duke.edu (H.E. Marshall).
} 


\section{Introduction}

Nitric oxide (NO) has long been recognized as a modulator of gene expression both in prokaryotic and eukaryotic cells. While NO-sensitive gene expression likely evolved in prokaryotes as a means to adapt to environmental nitrosative stress, its role in mammalian cells is primarily in stimulus-coupled, physiological signaling [1-3]. As such, the molecular mechanisms that govern NO-regulated gene expression in prokaryotes and eukaryotes vary widely. Whereas bacteria need to detect a general flux of NO in the context of a global, cellular response to nitrosative stress, mammalian cells require NO-sensing that is targeted (i.e. site-specific) and rapidly reversible in the context of signal transduction. The bulk of NO-regulated gene transcription in bacteria is mediated through modification of iron $(\mathrm{Fe})$ centered transcriptional regulons which, although highly sensitive to changes in cellular NO (as well as oxidative stress), are not rapidly reversible [4,5]. In contrast, the vast majority of NO-dependent gene transcription in mammalian cells is conferred by tightly regulated and specific protein S-nitrosylation, either through direct modification of transcriptional regulators or upstream intermediates in the respective signaling pathways.

Given the growing recognition and importance of protein S-nitrosylation in cellular physiology and pathophysiology, this review will focus on transcription factors and other modulators of gene expression that are regulated by S-nitrosylation. We seek to distinguish physiologic, stimulus-coupled S-nitrosylation from that which may occur as a consequence of exogenously-applied nitrosative stress. In this regard, the molecular mechanisms that induce S-nitrosylation as well as denitrosylation of these transcriptional regulators will also be discussed. As another review in this issue will cover the topic of S-nitrosylation in plant physiology, we will limit our discussion to S-nitrosylation regulating gene transcription in bacteria and mammalian cells only.

\section{NO-sensitive gene expression in bacteria}

In bacteria, NO induces the expression of enzymes that serve to protect the cell from nitrosative stress that ultimately could lead to cell stasis and death [6]. Bacteria are subjected to high levels of $\mathrm{NO}$ either in the process of nitrogen fixation (i.e. denitrification) or, in the case of pathogenic bacteria (e.g. E. coli), via NO production from immune-response cells (e.g. macrophages) [7]. In the case of denitrification, a cascade of redox-sensitive transcription factors is activated, among which is DNR. DNR primarily responds to cellular levels of nitrite $\left(\mathrm{NO}_{2}^{-}\right)$[8], reflecting the fact that nitrite is reduced to $\mathrm{NO}$ in bacteria by nitrite reductases.

Including DNR, thirteen distinct NO-sensitive regulons have been identified in E. coli, controlling the expression of enzymes involved in NO metabolism, iron homeostasis (including iron-sulfur cluster repair), and methionine biosynthesis [9]. Expression of the two primary NO-detoxifying enzymes, Hmp (flavohemoglobin) and NorV (flavorubredoxin), is regulated by iron-nitrosyl formation within the transcription factors NsrR and NorR, respectively [1]. In addition to NsrR, the expression of Hmp appears to also be at least partially regulated by the ferric uptake regulation protein (Fur) and FNR regulons [10]. In the case of Fur, the active form is a homodimer (FeFur) which contains a non-heme ferrous 
iron $\left(\mathrm{Fe}^{2+}\right)$ bound to amino acid oxygen and nitrogen groups. When the cellular iron concentration becomes low, FeFur loses $\mathrm{Fe}^{2+}$ and is no longer able to bind to specific DNA sequences. Under nitrosative conditions, the non-heme ferrous iron sensor is nitrosylated, which leads to decreased DNA binding and triggers the expression of genes that control iron uptake and storage [11]. Similarly, SoxRS, which regulates the transcription of oxidative response genes can be activated by either oxidation or nitrosylation of a [2Fe-2S] cluster in the SoxR sensor molecule [12]. When the SoxRS system is activated, bacteria gain resistance to NO-producing immune cells through increased expression of a number of different genes including manganese-dependent superoxide dismutase and the DNA repair enzyme endonuclease IV [13,14].

While not the primary molecular sensing mechanism, two bacterial regulons have been shown to be modulated by S-nitrosylation. A redox-sensitive cysteine (C203) in the Salmonella regulon SsrB can undergo either oxidation or S-nitrosylation thereby inhibiting SsrB DNA binding and preserving Salmonella pathogenicity [15]. Similarly, the transcription factor OxyR regulates the expression of bacterial antioxidant genes via redox modification of a single cysteine residue (C199) [16]. Oxidation (e.g. S-OH, S-SG) or nitrosylation (S-NO) of this thiol induces differential expression of antioxidant genes which are dependent upon the specific cysteine modification [17]. The transcriptional response is tied to distinct molecular conformational changes and DNA binding affinities of the redoxmodified OxyR. As such, OxyR may be an evolutionary precursor to mammalian transcription factors that display reactive thiols that are sensitive to both oxidation and nitrosylation (e.g. NF- $\kappa \mathrm{B}$ ). In addition, it has been proposed that the progression from $\mathrm{S}$ nitrosylation and reversible oxidative cysteine modifications (i.e. SOH, SSG) to irreversible cysteine oxidation (e.g. sulphonic acid $\left(\mathrm{SO}^{-}\right)$) represents a graded transition from physiological cell signaling to toxicity that occurs in the context of overwhelming nitrosative and oxidative stress [18].

\section{Nitrosative stress-induced gene expression in mammalian cells}

Similar to bacteria, an adaptive transcriptional response is observed in mammalian cells that are subjected to pathologically high levels of NO which occur in the context of dysregulated iNOS activity (e.g. sepsis). However, in contrast to bacteria, NO-metabolizing genes are not induced, rather genes that are predominantly involved in the cellular stress response.

Whereas some genes are directly activated by NO, others require additional cytokineinduced signals that occur in conjunction with iNOS expression [2]. In hepatocytes, for example, high output NO production (from iNOS) induces the transcription of genes coding for pro-inflammatory transcription factors, cytokines, cytokine receptors, proteins associated with cell proliferation and metabolism, and apoptosis [3].

Although not well delineated, the signaling mechanism(s) for nitrosative stress-induced gene expression in mammalian cells differs from bacteria in that the response is mediated primarily in an indirect manner, through NO activation of stress response signaling pathways (e.g. MAP kinases) and not via direct modification of transcriptional regulators [19]. A notable exception may be NO modification of zinc ( $\mathrm{Zn}$ )-finger transcription factors. A number of $\mathrm{Zn}$-finger transcription factors are involved in regulating the cellular stress 
response (e.g. Sp1, EGR-1) and have been shown to undergo S-nitrosylation under conditions of nitrosative stress [20]. SNO modification of these transcription factors will be discussed in detail later in this review. NO may also regulate gene transcription by altering cellular Zn levels as NO modification of the Zn-binding protein metallothionein leads to an increase in intracellular $\mathrm{Zn}$, resulting in the activation of the metal responsive transcription factor MTF-1, a partial regulator of stress response pathways [21].

Tyrosine nitration, a NO-induced protein modification that predominates under conditions of nitrosative stress, may also play a role in regulating the stress response in mammalian cells. $\mathrm{I} \kappa \mathrm{Ba}$ and $\mathrm{p} 65$, two proteins in the NF- $\kappa \mathrm{B}$ signaling pathway, have been shown to undergo tyrosine nitration with the modification affecting protein-protein interactions and an increase in downstream NF- $\kappa \mathrm{B}$ activity [22,23]. The tumor suppressor p53 also undergoes nitration under conditions of nitrosative stress with this modification inducing protein oligomerization, nuclear retention, and an increase in p53-dependent gene transcription [24]. Similarly, nitration of the glucocorticoid receptor (GR) enhances its nuclear translocation enhancing GR-dependent transcription [25]. GR-dependent transcription is also increased by nitration of histone deacetylase 2 (HDAC2) which inhibits its activity leading to greater histone acetylation, relaxation of the nucleosome structure, and increased transcriptional activity at the GR complex [26]. It is important to note, however, that tyrosine nitration, unlike S-nitrosylation, has not been demonstrated to be a reversible protein modification and thus should not be considered as a physiological mechanism by which genetic expression is regulated in mammalian cells.

\section{Physiological regulation of mammalian gene expression by NO}

\section{1. cGMP-mediated gene transcription}

Unlike bacteria, NO modulation of gene expression in mammalian cells occurs primarily in the context of physiological signaling and not through pathological nitrosative stress. NO achieves this goal either indirectly through an increase in cellular cGMP levels (via NO activation of guanylate cyclase) or through direct NO modification of protein thiol (i.e. Snitrosylation). cGMP regulates gene expression positively and negatively both at the transcriptional and posttranscriptional levels [27]. The principal mechanism by which cGMP modulates gene expression is through changes in transcription factor phosphorylation and/or expression. It is of interest that several of the transcription factors that are activated by cGMP, in particular, AP-1, EGR-1, and CREB are also regulated by NO via protein Snitrosylation [28]. cGMP-dependent gene expression is characterized best in cardiomyocytes, vascular smooth muscle (VSMC), and neuronal cells where NO-cGMP signaling is of paramount importance in regulating cell proliferation, survival, and differentiation [29]. In vascular smooth muscle cells, cGMP increases the expression of RhoA, MAP kinase phosphatase-1 (MKP-1), and vascular endothelial growth factor (VEGF) but decreases the expression of receptor guanylate cyclase A (rGC-A), and the cyclins A, $\mathrm{D} 1$, and $\mathrm{E}$ [30-32]. The transcriptional effects here are predominantly protein kinase $\mathrm{G}$ (PKG)-dependent although the mechanism by which PKG achieves specificity is unclear. 


\subsection{Protein S-nitrosylation in gene transcription}

While the importance of cGMP controlled gene transcription is firmly established and unquestioned, a growing body of evidence indicate protein S-nitrosylation is the predominant mechanism by which NO regulates gene transcription in mammalian cells with at least 14 mammalian transcription factors shown to be regulated directly by S-nitrosylation (Table 1). There are several reasons why S-nitrosylation holds a signaling advantage over cGMP in regulating gene transcription. Unlike cGMP, S-nitrosylation allows the targeted protein to respond to localized (i.e. subcellular) changes in NO that can be mediated by compartmentalized or direct protein-protein interaction with NO-producing enzymes (e.g. NOS). In this regard, several transcription factors (e.g. NF- $\kappa B$, PARP-1) are known to be regulated by stimulus-coupled, NOS-mediated S-nitrosylation [33,34]. Additional enzymatic mechanisms other than NOS may also mediate S-nitrosylation of transcriptional regulators. Possibilities here include $\mathrm{Cu}, \mathrm{Zn}$ superoxide dismutase (SOD) and ceruloplasmin both of which are facilitators of GSNO-mediated S-nitrosylation [35,36]. It seems likely, however, that additional metalloproteins will also be identified that function in the transfer of $\mathrm{NO}$ (as $\mathrm{NO}+)$ to protein thiol.

Similar to S-nitrosylation, stimulus-coupled denitrosylation of transcription factors has also been demonstrated, although the precise mechanisms are not fully elucidated. Both NF- $\kappa \mathrm{B}$ p65 and IKK $\beta$ undergo denitrosylation upon cytokine stimulation of respiratory epithelial cells $[34,37]$. A potential mediator of this process is thioredoxin (Trx), which has recently been shown to function in Fas-induced denitrosylation and activation of caspase-3 and is a well-known redox regulator of the NF- $\kappa$ B Rel proteins. While not known to directly metabolize S-nitrosylated proteins, S-nitrosoglutathione reductase (GSNOR), a glutathionedependent formaldehyde dehydrogenase, does indirectly affect protein denitrosylation by decreasing cellular GSNO levels, which are known to be in equilibrium with protein SNOs [38]. Protein disulfide isomerase and SOD are also known to catalyze the reduction of GSNO although this activity has not been demonstrated in the context of stimulus-coupled denitrosylation $[39,40]$.

In addition to the specificity afforded by spatial interactions with nitrosylating and denitrosylating enzymes, targeted S-nitrosylation of transcription factors can also be achieved by the presence of amino acid motifs, either in secondary or tertiary structure, that surround the reactive thiol [18]. For example, flanking acid-base motifs, which effectively decrease the pKa of the reactive thiol facilitating SNO formation and stabilization, are found in the DNA-binding domain (DBD) of the NF- $\kappa$ B Rel proteins, two of which, p50 and p65, are known to be regulated by S-nitrosylation [34,41]. In addition, a hydrophobic pocket surrounding the reactive cysteine also favors S-nitrosylation by increasing the ability of locally produced NO to react with molecular oxygen resulting in the formation of nitrosating species (e.g. $\mathrm{N}_{2} \mathrm{O}_{3}$ ) that then directly modify the thiol [42]. Given the specificity afforded by these spatial and molecular substrate characteristics, comparisons can be drawn between protein S-nitrosylation and O-phosphorylation in that both of these modifications exhibit substrate specificity and that the steady-state levels are enzymatically regulated. 


\section{S-nitrosylation of mammalian transcription factors}

\subsection{NF- $x B$}

The effect of NO and, in particular, S-nitrosylation on the NF- $\kappa \mathrm{B}$ pathway is well borne out. $\mathrm{NF}-\kappa \mathrm{B}$ regulates the transcriptional activation of numerous genes, particularly those involved in the inflammatory response, apoptosis, cell adhesion, differentiation and proliferation [43]. In addition, the expression of all three NOS isoforms is at least partially controlled by NF- $\kappa B$ [44-46]. NF- $\kappa B$ activity is exquisitely sensitive to cellular NO levels with multiple steps in the signaling pathway targeted by S-nitrosylation (Fig. 1). The prototypical member of the NF- $\mathrm{kB}$ family is the p50-p65 heterodimer which is constitutively expressed in most mammalian cells but held inactive in the cytoplasm by binding to the inhibitory I $\kappa \mathrm{B} a$ protein [47]. Upon stimulation, I $\kappa \mathrm{B} a$ is phosphorylated by

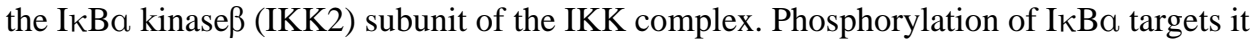
for ubiquitination and proteasomal degradation which allows for p50-p65 nuclear translocation and $\kappa \mathrm{B}$-dependent gene transcription. NO inhibits NF- $\kappa \mathrm{B}$-dependent DNA binding in a thiol-dependent manner through S-nitrosylation of the p50 monomer at a redoxsensitive cysteine (C62) located in the Rel DBD [41,48]. In addition, the binding partner of p50, p65, has also been shown to be targeted by S-nitrosylation in cytokine-stimulated respiratory epithelial cells and macrophages inhibiting NF-kB binding to the NOS2 promoter and deactivating NOS2 expression [34]. The physiological importance of this mechanism was recently demonstrated in the LPS-treated mouse lung where NF- $\kappa \mathrm{B}$ activation in the respiratory epithelium coincides with degradation of constitutively nitrosylated p65 and augmentation of cellular SNO and SNO-p65 levels prior to LPS treatment attenuates NF- $\kappa \mathrm{B}$ activation and subsequent inflammation [49]. Interestingly, Snitrosylation of NF- $\kappa \mathrm{B}$ p50 and p65 occurs at the same, conserved cysteine in the Rel DBD suggesting that S-nitrosylation may be a regulatory mechanism inherent to all Rel proteins [34].

Similar to the Rel proteins, IKK activity is also subject to both redox and NO regulation via modification of a conserved cysteine residue (C179) located within the reactive loop of the IKK2 subunit [37]. NO inhibits cytokine-induced IKK activity in lymphocytes and lung epithelium with the mechanism determined to be S-nitrosylation of this reactive thiol [37]. At baseline, IKK2 is maintained inactive by S-nitrosylation however TNFa stimulation induces rapid denitrosylation and activation of IKK, analogous to what is seen with NF- $\kappa B$ p65 [34]. In this regard, whether denitrosylation is a generalized cellular response to cytokine stimulation or a specific, coordinated process that initiates NF- $\kappa \mathrm{B}$ activation is unclear.

In addition to direct modification of NF- $\kappa \mathrm{B}$ proteins, $\mathrm{NO}$ can also alter NF- $\kappa \mathrm{B}$ activity through S-nitrosylation of proteins in other signal transduction pathways that cross-talk with $\mathrm{NF}-\kappa \mathrm{B}$. For example, NO inhibits TLR-4 activation of NF- $\kappa \mathrm{B}$ via S-nitrosylation of MyD88 [50]. S-nitrosylation of a specific cysteine residue within the TIR domain of MyD88 inhibits its ability to translocate to the cell membrane, interact with TIRAP, and bind to TRAF6, thereby preventing activation of the IKK complex. In addition to TLR-4, NF- $\kappa$ B activity can be modulated by protein S-nitrosylation in the JNK1 and ras-PI3K-Akt pathways, which is 
discussed in detail later in this review. Collectively, the impact of S-nitrosylation on NF- $\kappa \mathrm{B}$ signaling and gene transcription likely reflects feedback regulation and the immunomodulatory effects of iNOS, highlighting the importance of SNO metabolism in the pathophysiology of inflammatory disease [49].

\subsection{HIF-1}

Hypoxia-inducible factor-1 (HIF-1) is a transcription factor involved in the oxygendependent regulation of gene expression. While originally described as a regulator of erythropoietin, HIF-1 is now known to control the expression of a diverse group of genes involved in angiogenesis, apoptosis, inflammation, metabolism, and development [51]. HIF-1 is composed of two subunits, the basic-helix-loop-helix/Per-Arnt-Sim protein HIF-1a and the constitutively-expressed aryl hydrocarbon receptor nuclear translocator (ARNT) HIF-1 $\beta$ [52]. Under normoxic conditions, HIF-1 activity is negligible as proline residues in HIF-1a are modified by hydroxylation through the activity of oxygen-sensitive prolyl hydroxylase (PHD). Hydroxylation of HIF-1a induces interaction with the von HippelLindau-E3 ubiquitin ligase complex targeting HIF-1a for proteasomal degradation [53-57]. Under hypoxic conditions, the PHD enzymes are inactive but can be activated by NO [58]. Indeed, NO plays an integral and complex role in the regulation of the HIF-1 pathway (Fig. 2). Depending upon oxygen availability NO can either inhibit PHD (normoxic conditions) or activate it (hypoxic conditions) [59,60]. The sensing mechanism in this case appears to be NO interaction with a ferrous iron ligand located within the PHD active site and not protein S-nitrosylation. However, S-nitrosylation is known to increase HIF-1 activity by modifying HIF-1a at two distinct cysteine residues. S-nitrosylation of cysteine-533 in the oxygen degradation domain stabilizes HIF-1a by inhibiting its binding to the von-Hippel Lindau protein allowing for HIF-1a to interact with HIF-1 $\beta$ and undergo nuclear translocation [57]. S-nitrosylation of another redox-sensitive cysteine (C800) located within the C-terminal activation domain also increases HIF-1 activity in this case by facilitating HIF-1a binding to the co-activating p300/cyclic AMP response element binding (CREB) protein [61,62]. The pathophysiological significance of S-nitrosylation in the HIF pathway was recently demonstrated in a model of myocardial injury where SNO-HIF-1a was shown to bind to the VEGF promoter inducing angiogenesis and myocardial protection from ischemia [56].

\subsection{Activating protein-1 (AP-1)}

Activator protein-1 (AP-1) is a heterodimeric protein belonging to the basic leucine zipper (bZIP) transcription factor family that is composed of a Fos and Jun subunit with the primary activating form being c-Fos/c-Jun [63]. In contrast to the constitutively expressed NF- $\kappa$ B and HIF-1 proteins, activation of the AP-1 pathway occurs predominantly through increased transcription and/or phosphorylation of these subunits. AP-1 is important in the cellular stress response inducing the transcription of genes that function in the control of inflammation, cellular differentiation, and apoptosis, processes that all come under the influence of NO. In this regard, AP-1 has long been known to be sensitive to NO with regulation both through cGMP-dependent and independent mechanisms $[64,65]$.

AP-1 was one of the first mammalian transcription factors to demonstrate redox-sensitive DNA binding with this redox sensitivity conferred by a single conserved cysteine located in 
the DBD of both the c-Fos (C154) and c-Jun (C272) subunits [66]. Similar to NF- $\kappa B$, either oxidation or nitrosylation of these cysteine residues in Fos and Jun inhibits DNA binding [67]. Interestingly, GSNO can mediate S-glutathiolation of the same conserved cysteine in the c-Jun subunit in deference to trans-nitrosylation [68]. However, whether a particular redox thiol modification of the Fos/Jun subunits predominates in cell signaling or results in a varying transcriptional response akin to the bacterial regulon OxyR remains to be determined.

\subsection{NF-E2-related nuclear factor 2 (Nrf2)}

Nrf2 is a transcription factor which regulates genes that serve to protect cells from oxidative injury including $\mathrm{NAD}(\mathrm{P}) \mathrm{H}$ quinone oxidoreductase 1, glutamate-cysteine ligase, and heme oxygenase-1 (HO-1) [69]. At baseline, Nrf2 is maintained inactive in the cytoplasm by binding to Kelch-like ECH-associated protein 1 (Keap1), which targets Nrf2 for proteasomal degradation by serving as a binding adaptor to the Cul3-based E3 ubiquitin ligase complex [69]. NO has been shown to induce Nrf2-dependent antioxidant response element (ARE) transcription via two distinct mechanisms: protein kinase $\mathrm{C}$-delta $(\mathrm{PKC} \delta)$-mediated phosphorylation of Nrf2 serine 40 and S-nitrosylation and inhibition of a critical cysteine (C151) on Keap1 [70]. S-nitrosylation of Keap1 disrupts protein interaction with Nrf2 inhibiting its degradation and augmenting nuclear translocation [70-72]. The physiological importance of this mechanism has been demonstrated in cytokine-stimulated macrophages where NO activation of Nrf2 results in increased HO-1 expression which then serves to inhibit iNOS expression [73]. In addition to SNO modification of Keap1, NO can also increase ARE transcriptional activity through S-nitrosylation and inhibition of the nuclear export protein CRM1 which allows for the nuclear accumulation of Nrf2 [74].

\section{5. p53}

The tumor suppressor protein $\mathrm{p} 53$ regulates the transcription of genes that function in the control of the cell cycle, DNA repair, and apoptosis. Pathological levels of NO can activate p53 by inducing DNA strand breaks [75], but NO can also activate p53 through direct molecular modification. p53 is active as a tetramer which contains identical subunits composed of a $\mathrm{N}$-terminal transactivation domain, a DNA binding domain containing a $\mathrm{Zn}(\mathrm{Cys})_{3} \mathrm{His}$ cluster, and a $\mathrm{C}$-terminal domain which functions in protein oligomerization and regulation [76]. In addition to the zinc coordinating thiols, the DBD of p53 contains several other redox-sensitive cysteine residues that when oxidized disrupt p53 DNA binding [77]. While likely targets for NO, none of these cysteines, to date, has been demonstrated to undergo S-nitrosylation. However, NO has been shown to activate p53 through Snitrosylation and inhibition of the ubiquitin ligase Hdm2 [78]. P53 levels are normally kept in check by Hdm2-mediated proteasomal degradation, however SNO modification of Hdm2 prevents its nuclear translocation resulting in an increase in nuclear p53 levels and transcriptional activation. In addition to the inhibition of $\mathrm{Hdm} 2, \mathrm{NO}$ can also increase p53 activity by triggering its $\mathrm{p} 38$ MAPK-dependent phosphorylation (at serine 15) [79-81]. While the precise molecular mechanism here has not been discerned, S-nitrosylation is well known to modulate the activity of MAP kinases and phosphatases [82,83]. In addition, NO may also increase p53 activity via S-nitrosylation of the calcium-binding protein S100B, which is a known binding partner and regulator of p53 activity [84]. 


\subsection{Zinc finger transcription factors}

$\mathrm{Zn}$ finger domains are the most prevalent transcription factor DNA-binding motif with several different $\mathrm{Zn}$-coordinating amino acid sequences defined, the most common being $\mathrm{Zn}$ bound to two cysteine and two histidine residues (Cys2-His2) [85]. Zn-finger domains are known to be labile to NO with the thiol ligands susceptible to S-nitrosation which results in zinc release, protein conformational change, and disruption in transcription factor DNA binding [86]. Interestingly, despite the complete ejection of zinc from the protein, Snitrosylation of $\mathrm{Zn}$-finger thiolates has been shown to be reversible indicating that the redox status of the thiols and not the coordination of $\mathrm{Zn}$ is the primary limiting factor [87].

Members of the Zn finger-containing transcription factor family include Sp1, EGR-1, and Yin Yang 1 (YY1). Sp1 and EGR-1 are constitutively expressed and have prominent roles in the cellular stress response controlling both the basal and inducible expression of numerous genes [52]. Sp1 and EGR-1 contain three Cys2-His2 Zn fingers in their DBD all of which display redox-sensitivity [52]. Exposure of Sp1 or EGR-1 to pathological levels of NO completely abolishes their DNA binding suggesting that the Zn-finger DBD is a target of Snitrosylation $[87,88]$. Further evidence to support this mechanism is seen in neuronal cells where Sp1 undergoes interaction with nNOS resulting in the inhibition of DNA binding and decreased transcription of $\mathrm{Cu}, \mathrm{Zn}-\mathrm{SOD}$, a Sp1-dependent gene [89,90]. Surprisingly, NOS inhibition has been shown to decrease Sp1 activity in neuronal cells although here the effect appears to be dependent upon NO activation of Ras (by S-nitrosylation) and does not involve Sp1 directly [91]. Interestingly, eNOS is a Sp1-dependent gene with NO treatment of endothelial cells inhibiting Sp1 DNA binding resulting in a decrease of eNOS transcription [92]. In other cases, $\mathrm{NO}$ inhibition of $\mathrm{Sp} 1$ positively regulates gene transcription as demonstrated in leukocytes where NO increases TNFa expression in conjunction with a decrease in Sp1 binding to the TNFa promoter [93]. S-nitrosylation of EGR-1 also appears to play a role in regulating the inflammatory response with SNO inactivation of EGR-1 resulting in a decrease in IL-2 gene expression in cytokine-stimulated lymphocytes [87]. Similar to Sp1 and EGR-1, YY1 is a ubiquitously expressed transcription factor that functions in cell differentiation, replication, and apoptosis [94]. In this regard, Snitrosylation of YY1 results in upregulation of the Fas receptor and increased sensitization to apoptosis [95-97].

5.6.1. Nuclear hormone receptors-An important subclass of $\mathrm{Zn}$ finger transcription factors is the nuclear hormone receptor superfamily. The nuclear hormone receptors are unique in that they contain two $\mathrm{Zn}$ finger domains that are coordinated to the protein by four cysteine residues [98]. Members of the nuclear hormone receptor superfamily include the glucocorticoid receptor (GR), vitamin D3 receptor (VDR), retinoic X receptor (RXR), estrogen receptor (ER) and hepatocyte nuclear factor-4 (HNF4), all of which demonstrate NO-sensitive transcriptional activity. In the case of GR, NO inhibits ligand binding with the effect demonstrated to be thiol-reversible [99]. Conversely, NO inhibits the DNA binding activity of both VDR and RXR also in a thiol-reversible manner [86]. While the thiolreversible nature of these $\mathrm{NO}$ effects implicates S-nitrosylation, proof of this modification in either GR, VDR, or RXR to date is lacking. However, S-nitrosylation of the ER has been firmly established in cells exposed to physiological levels of NO with this modification 
resulting in the impairment of ER DNA binding and inhibition of estrogen-dependent gene transcription [100]. Interestingly, agonist-induced ER $\beta$ activation leads to an increase in eNOS-mediated protein S-nitrosylation which confers protection from ischemia/reperfusion injury [101,102]. Another member of the nuclear hormone receptor family, HNF4, regulates the expression of P450 detoxifying enzymes in the liver [103]. Under inflammatory conditions, NO suppresses HNF4 DNA binding in hepatocytes resulting in a decrease in cytochrome P450 expression [104,105]. In lung epithelial cells, NO was recently shown to inhibit DNA binding of a related family member, hepatocyte nuclear factor 3 (HNF-3), in this case leading to the decreased expression of surfactant protein B (SP-B) [106].

5.6.2. poly(ADP-ribose) polymerase (PARP)—The PARP family catalyzes the addition of ADP-ribose polymers onto DNA binding proteins and functions in the repair of DNA strand breaks, control of apoptosis, and pro-inflammatory gene expression [107]. PARPs contain two Zn-fingers which are located in the protein's N-terminal DBD. The prototypical and most highly expressed member of the family, PARP1, acts as a co-activator of several different transcription factors including AP-1 and NF- $\mathrm{BB}$ [108]. Inhibition of PARP-1 activity results in decreased NF- $\kappa B$-dependent expression of immunomodulatory genes, in particular iNOS [109]. Similar to NF- $\kappa$ B, S-nitrosylation of PARP-1 occurs in the setting of cytokine stimulation, is iNOS-dependent, and functions as feedback inhibition for continued iNOS expression by decreasing binding and transactivation at the iNOS promoter [33]. Whether S-nitrosylation alters PARP-1 catalytic function (i.e. ADP-ribosylation) as well remains unclear but could represent a dual mechanism to limit excessive PARP-1 activity and iNOS expression [33].

\subsection{Heterogeneous nuclear ribonucleoproteins (hnRNP)}

Heterogeneous nuclear ribonucleoproteins (hnRNP) regulate gene expression both at the transcriptional and post-transcriptional levels [110]. hnRNPs are important modulators of the inflammatory response functioning to control the expression of TNFa, IL-1 $\beta$, cyclooxygenase-2, and iNOS [111]. In the macrophage, hnRNPs regulate iNOS expression by binding to the $3^{\prime}$-untranslated region of iNOS mRNA tagging it for degradation. With cytokine stimulation, hnRNP levels and hnRNP-iNOS mRNA complex formation decrease resulting in greater iNOS protein expression [112,113]. iNOS activity, in turn, has been shown to induce S-nitrosylation of hnRNP A/B inhibiting its binding to the osteopontin promoter in cytokine-stimulated macrophages $[114,115]$. In vitro analysis has determined the site of hnRNP S-nitrosylation to be cysteine 104 with DNA binding inhibition by SNO shown to be thiol-reversible [115]. Interestingly, another ribonucleoprotein, hnRNP-U, binds to the same promoter site as hnRNP-A/B and augments osteopontin expression. hnRNP-A/B and hnRNP-U proteins, thus, serve antagonistic transcriptional regulatory functions in LPSstimulated macrophages [116].

\section{Transcriptional regulation via S-nitrosylation in cell signaling pathways}

\section{1. c-Jun N-terminal kinase (JNK) pathway}

The JNK MAP pathway is activated by a wide variety of biological and environmental stimuli with the downstream response mediated primarily by targeted phosphorylation and 
activation of transcription factors [117]. While c-Jun is the transcription factor that is the best delineated target of JNK, several other transcription factors including ATF-2, Elk1, and p53 are also substrates. In general, JNK functions in pro-inflammatory and pro-apoptotic signaling. The JNK pathway can initiate apoptosis by phosphorylation and inhibition of antiapoptotic $\mathrm{Bcl} 2$ proteins and the increased transcription of pro-apototic proteins, which is predominantly mediated through activation of the SNO-sensitive transcription factor AP-1 [118]. SNOs are known to protect the cell from apoptosis, in part, through inhibition of JNK pathway [119]. In macrophages, cytokine-stimulated iNOS activity induces S-nitrosylation of JNK1 (at Cysteine 116) inhibiting its activity [82]. Likewise, nNOS serves to regulate JNK1 in a similar fashion in neurons that are subjected to ischemia-reperfusion injury [120]. Disruption of the interaction between JNK1 and c-Jun may be an integral part of the mechanism underlying the negative regulation of the JNK signaling pathway by SNO [121]. Apoptosis signal-regulating kinase 1 (ASK1) is another protein in the JNK pathway that is inhibited by iNOS-mediated S-nitrosylation [122]. ASK1 lies upstream of JNK, with SNO modification of ASK1 at cysteine 869 altering its ability to bind and phosphorylate MAP kinase kinase substrates [123,124]. Interestingly, the dual specificity phosphatase MKP7, which shows functional specificity towards substrates in the JNK pathway, is inhibited by eNOS-mediated S-nitrosylation which in this case results in JNK3 activation [83].

\subsection{Ras pathway}

Ras proteins comprise a family of small GTPases that transduce signals from the cell membrane, most notably growth factor receptors, to downstream effector pathways which include ERK, Jak-STAT, and phosphoinositide 3-kinase (PI3K)-Akt [124]. In this context, Ras indirectly leads to the activation of numerous transcription factors, many of which are known to be regulated by S-nitrosylation (e.g. CREB, AP-1, NF- $\kappa$ B). However, the activity of several ras pathway proteins, including ras itself, is also known to be regulated by $\mathrm{S}$ nitrosylation. Ras is unique in that it is one of the few cellular proteins whose activity is enhanced by S-nitrosylation. S-nitrosylation of cysteine118 in p21ras stimulates guanine nucleotide exchange leading to activation of downstream ras pathways [125]. For example, in neurons, SNO-modified p21ras induces stimulation of ATP-sensitive potassium K-ATP channels which function in the protection from ischemic injury [126]. In macrophages, Snitrosylation of $\mathrm{p} 21$ ras increases the expression of the pro-apoptotic protein BNIP3 (via the ERK-HIF pathway) and initiating apoptosis [127]. Similarly, N-Ras undergoes eNOSmediated S-nitrosylation and activation in antigen-stimulated T cells, again resulting in ERK activation and cell death [128,129].

While S-nitrosylation activates ras proteins, other targets in the ras signaling pathway are inhibited by S-nitrosylation. The activity of Akt/PKB, which lies downstream of PI3K in the ras pathway, is attenuated by NO via S-nitrosylation at cysteine 224 [130]. Akt is an important regulator of cellular metabolism and SNO-Akt levels are increased in the muscle of diabetic $(\mathrm{db} / \mathrm{db})$ mice and aged rats suggesting that S-nitrosylation of Akt has pathophysiological significance $[130,131]$. Upstream from ras, SNO reversibly inhibits epidermal growth factor receptor tyrosine kinase activity through S-nitrosylation of two distinct cysteines (C166 and C305) [132,133]. Conversely, protein tyrosine phosphatase 1B (PT1B) activity is inactivated by S-nitrosylation of a cysteine located in its active site 
[134,135]. Interestingly, S-nitrosylation of PT1B has been shown to occur in the setting of cellular oxidative stress and thus may be a mechanism to prevent irreversible oxidation of the redox active cysteine [136]. Another phosphatase in the ras signaling pathway, PTEN, has also been shown to be targeted by S-nitrosylation with the modification not only inhibiting phosphatase activity but enhancing protein degradation as well [137,138]. PTEN serves to dephosphorylate phosphatidylinositol 3,4,5-trisphosphate (PIP3), the primary product of PI3K, which would function to attenuate Akt activation. Importantly, loss of PTEN activity has been demonstrated in neoplastic and neurodegenerative disorders, where SNO metabolism is known to be deranged $[137,139]$.

\section{S-nitrosylation in the nucleus}

\subsection{Glyceraldehyde-3-phosphate dehydrogenase (GAPDH)}

Given the obvious importance of protein S-nitrosylation within the nucleus, insight into defining the process by which nuclear proteins are modified by SNO has been of great interest. Simple diffusion of NO across the nuclear membrane seems an unlikely mechanism given the potential for deleterious nitration reactions, in particular that involving DNA, and while transport of low molecular weight SNO would resolve this issue, specificity here is also lacking. However, protein trans-nitrosylation reactions do have the potential for specificity with SNO-GAPDH being an attractive candidate in this role. GAPDH was one of the first proteins to be identified as a target for S-nitrosylation [140]. Initially, it was felt that S-nitrosylation of GAPDH functioned primarily to inhibit GAPDH enzymatic activity. It was later determined that S-nitrosylation of GAPDH initiates its binding to the E3 ubiquitin ligase Siah1, allowing the Siah-GAPDH complex to undergo nuclear translocation, which then leads to the initiation of apoptosis [141]. The process is dependent upon nuclear GAPDH activating p300/CBP acetylase activity [142]. More recently, it has been determined that SNO-GAPDH also functions in the transnitrosylation of nuclear proteins [143]. Targets include the deacetylating enzyme sirtuin-1 (SIRT1), HDAC2, and DNAactivated protein kinase (DNA-PK) [143]. The process is Siah-dependent with the transfer of SNO from GAPDH (cysteine 150) to the target proteins occurring within the nucleus. Whether SNO-GAPDH similarly targets transcription factors (e.g. NF- $\mathrm{kB}$ ) for Snitrosylation in the nucleus remains to be determined.

\subsection{Nuclear activity of NOS}

The three principal isoforms of NOS: nNOS, eNOS and iNOS are found primarily in the cytoplasm or, in the case of eNOS, attached to the plasma membrane. Because NO is an extremely reactive and short-lived molecule, the subcellular localization of NOS is a primary determinant of its physiological activity [144]. In this regard, a growing number of proteins that are regulated by S-nitrosylation have been shown to require direct binding or compartmentalized interaction with NOS [145]. In this context, nuclear translocation of NOS is another potential mechanism by which SNO modification of intranuclear proteins may be achieved. Evidence exists for all three NOS isoforms undergoing nuclear translocation [146-148]. Data to support a physiological role in the nucleus, however, is strongest for eNOS. G-protein coupled activation of hepatocytes induces eNOS translocation from the plasma membrane into the nucleus where it induces iNOS transcription through 
increased NF- $\kappa \mathrm{B}$ activation [149]. These results support earlier findings that eNOS augments iNOS expression in cytokine-stimulated macrophages [150]. Furthermore, 17betaestradiol stimulation of endothelial cells also induces rapid eNOS nuclear translocation in this case binding to the ER at the telomerase (hTERT) promoter leading to an increase in hTERT transcription [151]. Whether either of these responses is mediated by protein Snitrosylation is unclear, however given that both NF- $\mathrm{kB}$ and the ER are known SNO targets, this possibility would seem likely.

\subsection{Histone acetylation/deacetylation}

By inducing relaxation of the nucleosome, histone acetylation promotes gene transcription and histone acetylation has been shown to be an important factor in regulating the expression of all three NOS isoforms [152-154]. The primary mechanism here appears to be dependent on p300/CREB-binding protein binding which enhances NF- $\kappa B$-dependent NOS gene transcription [155]. NO, in turn, is a key regulator of histone deacetylase (HDAC) function. In neuronal cells, brain-derived neurotrophic factor (BDNF) triggers NO synthesis and S-nitrosylation of HDAC2, leading to the dissociation of HDAC2 from the Fos, EGR-1, VEGF, and nNOS promoters and an increase in their transcriptional activation [156,157]. NO inhibition of HDAC has been associated with the pathogenesis of Duchenne muscular dystrophy, highlighting the pathophysiological importance of this mechanism [158,159]. Interestingly, NO has also been shown to increase nuclear translocation of HDAC in endothelial cells, although this mechanism is via activation of protein phosphatase $2 \mathrm{~A}$ and not through SNO modification of HDAC [160]. More recently GAPDH, which undergoes nuclear translocation upon S-nitrosylation, was shown to bind and trans-nitrosylate HDAC2, delineating a mechanism by which S-nitrosylation of HDAC may be regulated [143].

\subsection{Nuclear import and export}

The process of nuclear protein import and export, a key factor in the regulation of gene transcription, has also demonstrated sensitivity to SNO. For example, TNFa stimulation induces S-nitrosylation and nuclear translocation of the chloride intracellular channel protein 4 (CLIC4) [161]. SNO modification of CLIC4 results in a change in protein conformation and enhanced binding to the nuclear pore complex proteins importina and Ran GTPase. Interestingly, both nuclear importin and Ran have also been shown to undergo Snitrosylation, although the physiological importance has yet to be determined [162,163]. Furthermore, NO induces nuclear translocation of thioredoxin-1 which is mediated, in part, by importina via redox modification of cysteine 69 in Trx [164], again implicating Snitrosylation in the process.

S-nitrosylation of the primary nuclear export protein, karyopherin chromosomal region maintenance 1 (CRM1), has been shown to inhibit its activity by disrupting CRM1 binding to nuclear export signals (NES) [74]. SNO inhibition of CRM1 is one mechanism by which NO evokes an increase in nuclear Nrf2 levels and ARE-dependent gene transcription [74]. On the other hand, NO increases CRM1-dependent nuclear export of redox factor-1 (REF-1), although here S-nitrosylation of Ref-1 (at cysteines 93 and 310), and not CRM1 modification, is the triggering mechanism [165]. It is important to note that Ref-1 regulates the DNA binding of AP-1, NF- $\mathrm{kB}$, and other redox-sensitive transcription factors by 
reducing reactive cysteines in their respective DBD [166], but whether S-nitrosylation affects this activity as well is unclear.

\section{Conclusion}

Accrued evidence leaves little doubt that protein S-nitrosylation plays a crucial role in the regulation of gene transcription. Given the development of increasingly sensitive techniques to detect endogenous SNO-modified proteins, the list of transcription factors identified as being regulated by S-nitrosylation continues to grow. Placement of these SNO-modified proteins into physiological context is imperative and is best achieved through a better understanding of the mechanisms by which transcriptional regulators are targeted for Snitrosylation/denitrosylation. Elucidation of these pathways is likely to result in the development of novel therapeutic strategies for cancer, sepsis, and other diseases where dysregulation of SNO metabolism and gene transcription are intimately associated.

\section{Acknowledgments}

This work was supported by a grant from the National Institutes of Health HL092994 (HEM). The authors thank Matthew Foster for helpful comments.

\section{References}

1. Hyduke DR, Jarboe LR, Tran LM, Chou KJ, Liao JC. Integrated network analysis identifies nitric oxide response networks and dihydroxyacid dehydratase as a crucial target in Escherichia coli. Proc Natl Acad Sci U S A. 2007; 104:8484-8489. [PubMed: 17494765]

2. Turpaev K, Bouton C, Diet A, Glatigny A, Drapier JC. Analysis of differentially expressed genes in nitric oxide-exposed human monocytic cells. Free Radic Biol Med. 2005; 38:1392-1400. [PubMed: 15855057]

3. Zamora R, Vodovotz Y, Aulak KS, Kim PK, Kane JM III, Alarcon L, Stuehr DJ, Billiar TR. A DNA microarray study of nitric oxide-induced genes in mouse hepatocytes: implications for hepatic heme oxygenase-1 expression in ischemia/reperfusion. Nitric Oxide. 2002; 7:165-186. [PubMed: 12381414]

4. Membrillo-Hernandez J, Coopamah MD, Channa A, Hughes MN, Poole RK. A novel mechanism for upregulation of the Escherichia coli $\mathrm{K}-12 \mathrm{hmp}$ (flavohaemoglobin) gene by the 'NO releaser', S-nitrosoglutathione: nitrosation of homocysteine and modulation of MetR binding to the glyA-hmp intergenic region. Mol Microbiol. 1998; 29:1101-1112. [PubMed: 9767577]

5. Flatley J, Barrett J, Pullan ST, Hughes MN, Green J, Poole RK. Transcriptional responses of Escherichia coli to S-nitrosoglutathione under defined chemostat conditions reveal major changes in methionine biosynthesis. J Biol Chem. 2005; 280:10065-10072. [PubMed: 15647275]

6. Tyurina YY, Basova LV, Konduru NV, Tyurin VA, Potapovich AI, Cai P, Bayir H, Stoyanovsky D, Pitt BR, Shvedova AA, Fadeel B, Kagan VE. Nitrosative stress inhibits the aminophospholipid translocase resulting in phosphatidylserine externalization and macrophage engulfment: implications for the resolution of inflammation. J Biol Chem. 2007; 282:8498-8509. [PubMed: 17229723]

7. Poole RK. Nitric oxide and nitrosative stress tolerance in bacteria. Biochem Soc Trans. 2005; 33:176-180. [PubMed: 15667299]

8. Hasegawa N, Arai H, Igarashi Y. Activation of a consensus FNR-dependent promoter by DNR of Pseudomonas aeruginosa in response to nitrite. FEMS Microbiol Lett. 1998; 166:213-217. [PubMed: 9770276]

9. Spiro S. Regulators of bacterial responses to nitric oxide. FEMS Microbiol Rev. 2007; 31:193-211. [PubMed: 17313521] 
10. Pullan ST, Gidley MD, Jones RA, Barrett J, Stevanin TM, Read RC, Green J, Poole RK. Nitric oxide in chemostat-cultured Escherichia coli is sensed by Fnr and other global regulators: unaltered methionine biosynthesis indicates lack of S nitrosation. J Bacteriol. 2007; 189:18451855. [PubMed: 17189370]

11. Mukhopadhyay P, Zheng M, Bedzyk LA, LaRossa RA, Storz G. Prominent roles of the NorR and Fur regulators in the Escherichia coli transcriptional response to reactive nitrogen species. Proc Natl Acad Sci U S A. 2004; 101:745-750. [PubMed: 14718666]

12. Ding H, Demple B. Direct nitric oxide signal transduction via nitrosylation of iron-sulfur centers in the SoxR transcription activator. Proc Natl Acad Sci U S A. 2000; 97:5146-5150. [PubMed: 10805777]

13. Lee JH, Lee KL, Yeo WS, Park SJ, Roe JH. SoxRS-mediated lipopolysaccharide modification enhances resistance against multiple drugs in Escherichia coli. J Bacteriol. 2009; 191:4441-4450. [PubMed: 19376854]

14. Lee PE, Demple B, Barton JK. DNA-mediated redox signaling for transcriptional activation of SoxR. Proc Natl Acad Sci U S A. 2009; 106:13164-13168. [PubMed: 19651620]

15. Husain M, Jones-Carson J, Song M, McCollister BD, Bourret TJ, Vazquez-Torres A. Redox sensor SsrB Cys203 enhances Salmonella fitness against nitric oxide generated in the host immune response to oral infection. Proc Natl Acad Sci U S A. 2010; 107:14396-14401. [PubMed: 20660761]

16. Hausladen A, Privalle CT, Keng T, DeAngelo J, Stamler JS. Nitrosative stress: activation of the transcription factor OxyR. Cell. 1996; 86:719-729. [PubMed: 8797819]

17. Kim SO, Merchant K, Nudelman R, Beyer WF Jr, Keng T, DeAngelo J, Hausladen A, Stamler JS. OxyR: a molecular code for redox-related signaling. Cell. 2002; 109:383-396. [PubMed: 12015987]

18. Hess DT, Matsumoto A, Kim SO, Marshall HE, Stamler JS. Protein S-nitrosylation: purview and parameters. Nat Rev Mol Cell Biol. 2005; 6:150-166. [PubMed: 15688001]

19. Thum T, Bauersachs J. Microarray-based gene expression profiling to elucidate cellular responses to nitric oxide - a review from an analytical and biomedical point of view. J Chromatogr B Analyt Technol Biomed Life Sci. 2007; 851:3-11.

20. Kronke G, Bochkov VN, Huber J, Gruber F, Bluml S, Furnkranz A, Kadl A, Binder BR, Leitinger N. Oxidized phospholipids induce expression of human heme oxygenase-1 involving activation of cAMP-responsive element-binding protein. J Biol Chem. 2003; 278:51006-51014. [PubMed: 14523007]

21. Stitt MS, Wasserloos KJ, Tang X, Liu X, Pitt BR, St Croix CM. Nitric oxide-induced nuclear translocation of the metal responsive transcription factor, MTF-1 is mediated by zinc release from metallothionein. Vascul Pharmacol. 2006; 44:149-155. [PubMed: 16423564]

22. Park SW, Huq MD, Hu X, Wei LN. Tyrosine nitration on p65: a novel mechanism to rapidly inactivate nuclear factor-kappaB. Mol Cell Proteomics. 2005; 4:300-309. [PubMed: 15657065]

23. Yakovlev VA, Barani IJ, Rabender CS, Black SM, Leach JK, Graves PR, Kellogg GE, Mikkelsen RB. Tyrosine nitration of IkappaBalpha: a novel mechanism for NF-kappaB activation. Biochemistry. 2007; 46:11671-11683. [PubMed: 17910475]

24. Yakovlev VA, Bayden AS, Graves PR, Kellogg GE, Mikkelsen RB. Nitration of the tumor suppressor protein $\mathrm{p} 53$ at tyrosine 327 promotes p53 oligomerization and activation. Biochemistry. 2010; 49:5331-5339. [PubMed: 20499882]

25. Paul-Clark MJ, Roviezzo F, Flower RJ, Cirino G, Soldato PD, Adcock IM, Perretti M. Glucocorticoid receptor nitration leads to enhanced anti-inflammatory effects of novel steroid ligands. J Immunol. 2003; 171:3245-3252. [PubMed: 12960354]

26. Ito K, Herbert C, Siegle JS, Vuppusetty C, Hansbro N, Thomas PS, Foster PS, Barnes PJ, Kumar RK. Steroid-resistant neutrophilic inflammation in a mouse model of an acute exacerbation of asthma. Am J Respir Cell Mol Biol. 2008; 39:543-550. [PubMed: 18474669]

27. Pilz RB, Casteel DE. Regulation of gene expression by cyclic GMP. Circ Res. 2003; 93:10341046. [PubMed: 14645134]

28. Marshall HE, Merchant K, Stamler JS. Nitrosation and oxidation in the regulation of gene expression. FASEB J. 2000; 14:1889-1900. [PubMed: 11023973] 
29. Balligand JL, Cannon PJ. Nitric oxide synthases and cardiac muscle. Autocrine and paracrine influences. Arterioscler Thromb Vasc Biol. 1997; 17:1846-1858. [PubMed: 9351345]

30. Sandu OA, Ito M, Begum N. Selected contribution: insulin utilizes NO/cGMP pathway to activate myosin phosphatase via Rho inhibition in vascular smooth muscle. J Appl Physiol. 2001; 91:1475-1482. [PubMed: 11509551]

31. Sauzeau V, Rolli-Derkinderen M, Marionneau C, Loirand G, Pacaud P. RhoA expression is controlled by nitric oxide through cGMP-dependent protein kinase activation. J Biol Chem. 2003; 278:9472-9480. [PubMed: 12524425]

32. Tanner FC, Meier P, Greutert H, Champion C, Nabel EG, Luscher TF. Nitric oxide modulates expression of cell cycle regulatory proteins: a cytostatic strategy for inhibition of human vascular smooth muscle cell proliferation. Circulation. 2000; 101:1982-1989. [PubMed: 10779466]

33. Yu Z, Kuncewicz T, Dubinsky WP, Kone BC. Nitric oxide-dependent negative feedback of PARP-1 trans-activation of the inducible nitric-oxide synthase gene. J Biol Chem. 2006; 281:9101-9109. [PubMed: 16464859]

34. Kelleher ZT, Matsumoto A, Stamler JS, Marshall HE. NOS2 regulation of NF-kappaB by Snitrosylation of p65. J Biol Chem. 2007; 282:30667-30672. [PubMed: 17720813]

35. Romeo AA, Capobianco JA, English AM. Superoxide dismutase targets NO from GSNO to Cysbeta93 of oxyhemoglobin in concentrated but not dilute solutions of the protein. J Am Chem Soc. 2003; 125:14370-14378. [PubMed: 14624585]

36. Mani K, Cheng F, Havsmark B, David S, Fransson LA. Involvement of glycosylphosphatidylinositol-linked ceruloplasmin in the copper/zinc-nitric oxide-dependent degradation of glypican-1 heparan sulfate in rat C6 glioma cells. J Biol Chem. 2004; 279:1291812923. [PubMed: 14707133]

37. Reynaert NL, Ckless K, Korn SH, Vos N, Guala AS, Wouters EF, van der Vliet A, JanssenHeininger YM. Nitric oxide represses inhibitory kappaB kinase through S-nitrosylation. Proc Natl Acad Sci U S A. 2004; 101:8945-8950. [PubMed: 15184672]

38. Liu L, Hausladen A, Zeng M, Que L, Heitman J, Stamler JS. A metabolic enzyme for Snitrosothiol conserved from bacteria to humans. Nature. 2001; 410:490-494. [PubMed: 11260719]

39. Johnson MA, Macdonald TL, Mannick JB, Conaway MR, Gaston B. Accelerated s-nitrosothiol breakdown by amyotrophic lateral sclerosis mutant copper, zinc-superoxide dismutase. J Biol Chem. 2001; 276:39872-39878. [PubMed: 11518706]

40. Sliskovic I, Raturi A, Mutus B. Characterization of the S-denitrosation activity of protein disulfide isomerase. J Biol Chem. 2005; 280:8733-8741. [PubMed: 15611098]

41. Marshall HE, Stamler JS. Inhibition of NF-kappa B by S-nitrosylation. Biochemistry. 2001; 40:1688-1693. [PubMed: 11327828]

42. Ascenzi P, Colasanti M, Persichini T, Muolo M, Polticelli F, Venturini G, Bordo D, Bolognesi M. Re-evaluation of amino acid sequence and structural consensus rules for cysteine-nitric oxide reactivity. Biol Chem. 2000; 381:623-627. [PubMed: 10987371]

43. Diatchenko L, Romanov S, Malinina I, Clarke J, Tchivilev I, Li X, Makarov SS. Identification of novel mediators of NF-kappaB through genome-wide survey of monocyte adherence-induced genes. J Leukoc Biol. 2005; 78:1366-1377. [PubMed: 16204640]

44. Hall AV, Antoniou H, Wang Y, Cheung AH, Arbus AM, Olson SL, Lu WC, Kau CL, Marsden PA. Structural organization of the human neuronal nitric oxide synthase gene (NOS1). J Biol Chem. 1994; 269:33082-33090. [PubMed: 7528745]

45. Xie QW, Kashiwabara Y, Nathan C. Role of transcription factor NF-kappa B/Rel in induction of nitric oxide synthase. J Biol Chem. 1994; 269:4705-4708. [PubMed: 7508926]

46. Park JY, Farrance IK, Fenty NM, Hagberg JM, Roth SM, Mosser DM, Wang MQ, Jo H, Okazaki T, Brant SR, Brown MD. NFKB1 promoter variation implicates shear-induced NOS3 gene expression and endothelial function in prehypertensives and stage I hypertensives. Am J Physiol Heart Circ Physiol. 2007; 293:H2320-H2327. [PubMed: 17644577]

47. Hayden MS, Ghosh S. Shared principles in NF-kappaB signaling. Cell. 2008; 132:344-362. [PubMed: 18267068]

48. Matthews JR, Botting CH, Panico M, Morris HR, Hay RT. Inhibition of NF-kappaB DNA binding by nitric oxide. Nucleic Acids Res. 1996; 24:2236-2242. [PubMed: 8710491] 
49. Marshall HE, Potts EN, Kelleher ZT, Stamler JS, Foster WM, Auten RL. Protection from lipopolysaccharide-induced lung injury by augmentation of airway S-nitrosothiols. Am J Respir Crit Care Med. 2009; 180:11-18. [PubMed: 19324975]

50. Into T, Inomata M, Nakashima M, Shibata K, Hacker H, Matsushita K. Regulation of MyD88dependent signaling events by $\mathrm{S}$ nitrosylation retards toll-like receptor signal transduction and initiation of acute-phase immune responses. Mol Cell Biol. 2008; 28:1338-1347. [PubMed: 18086890]

51. Semenza GL. Hypoxia-inducible factor 1 (HIF-1) pathway. Sci STKE. 2007:cm8. [PubMed: 17925579]

52. Kroncke KD. Nitrosative stress and transcription. Biol Chem. 2003; 384:1365-1377. [PubMed: 14669980]

53. Sandau KB, Faus HG, Brune B. Induction of hypoxia-inducible-factor 1 by nitric oxide is mediated via the PI 3K pathway. Biochem Biophys Res Commun. 2000; 278:263-267. [PubMed: 11071882]

54. Kimura H, Weisz A, Ogura T, Hitomi Y, Kurashima Y, Hashimoto K, D’Acquisto F, Makuuchi M, Esumi H. Identification of hypoxia-inducible factor 1 ancillary sequence and its function in vascular endothelial growth factor gene induction by hypoxia and nitric oxide. J Biol Chem. 2001; 276:2292-2298. [PubMed: 11056166]

55. Palmer LA, Gaston B, Johns RA. Normoxic stabilization of hypoxia-inducible factor-1 expression and activity: redox-dependent effect of nitrogen oxides. Mol Pharmacol. 2000; 58:1197-1203. [PubMed: 11093754]

56. Lima B, Lam GK, Xie L, Diesen DL, Villamizar N, Nienaber J, Messina E, Bowles D, Kontos CD, Hare JM, Stamler JS, Rockman HA. Endogenous S-nitrosothiols protect against myocardial injury. Proc Natl Acad Sci U S A. 2009; 106:6297-6302. [PubMed: 19325130]

57. Li F, Sonveaux P, Rabbani ZN, Liu S, Yan B, Huang Q, Vujaskovic Z, Dewhirst MW, Li CY. Regulation of HIF-1alpha stability through S-nitrosylation. Mol Cell. 2007; 26:63-74. [PubMed: 17434127]

58. Wang F, Sekine H, Kikuchi Y, Takasaki C, Miura C, Heiwa O, Shuin T, Fujii-Kuriyama Y, Sogawa K. HIF-1alpha-prolyl hydroxylase: molecular target of nitric oxide in the hypoxic signal transduction pathway. Biochem Biophys Res Commun. 2002; 295:657-662. [PubMed: 12099689]

59. Metzen E, Zhou J, Jelkmann W, Fandrey J, Brune B. Nitric oxide impairs normoxic degradation of HIF-1alpha by inhibition of prolyl hydroxylases. Mol Biol Cell. 2003; 14:3470-3481. [PubMed: 12925778]

60. Callapina M, Zhou J, Schnitzer S, Metzen E, Lohr C, Deitmer JW, Brune B. Nitric oxide reverses desferrioxamine- and hypoxia-evoked HIF-1alpha accumulation-implications for prolyl hydroxylase activity and iron. Exp Cell Res. 2005; 306:274-284. [PubMed: 15878351]

61. Yasinska IM, Sumbayev VV. S-nitrosation of Cys-800 of HIF-1alpha protein activates its interaction with p300 and stimulates its transcriptional activity. FEBS Lett. 2003; 549:105-109. [PubMed: 12914934]

62. Cho H, Ahn DR, Park H, Yang EG. Modulation of p300 binding by posttranslational modifications of the C-terminal activation domain of hypoxia-inducible factor-1alpha. FEBS Lett. 2007; 581:1542-1548. [PubMed: 17382325]

63. Shaulian E, Karin M. AP-1 as a regulator of cell life and death. Nat Cell Biol. 2002; 4:E131-E136. [PubMed: 11988758]

64. Pilz RB, Suhasini M, Idriss S, Meinkoth JL, Boss GR. Nitric oxide and cGMP analogs activate transcription from AP-1-responsive promoters in mammalian cells. FASEB J. 1995; 9:552-558. [PubMed: 7737465]

65. Tsurumi Y, Murohara T, Krasinski K, Chen D, Witzenbichler B, Kearney M, Couffinhal T, Isner JM. Reciprocal relation between VEGF and NO in the regulation of endothelial integrity. Nat Med. 1997; 3:879-886. [PubMed: 9256279]

66. Abate C, Patel L, Rauscher FJ III, Curran T. Redox regulation of fos and jun DNA-binding activity in vitro. Science. 1990; 249:1157-1161. [PubMed: 2118682] 
67. Nikitovic D, Holmgren A, Spyrou G. Inhibition of AP-1 DNA binding by nitric oxide involving conserved cysteine residues in Jun and Fos. Biochem Biophys Res Commun. 1998; 242:109-112. [PubMed: 9439619]

68. Klatt P, Molina EP, Lamas S. Nitric oxide inhibits c-Jun DNA binding by specifically targeted Sglutathionylation. J Biol Chem. 1999; 274:15857-15864. [PubMed: 10336489]

69. Kaspar JW, Niture SK, Jaiswal AK. Nrf2:INrf2 (Keap1) signaling in oxidative stress. Free Radic Biol Med. 2009; 47:1304-1309. [PubMed: 19666107]

70. Niture SK, Jain AK, Jaiswal AK. Antioxidant-induced modification of INrf2 cysteine 151 and PKC-delta-mediated phosphorylation of Nrf2 serine 40 are both required for stabilization and nuclear translocation of Nrf2 and increased drug resistance. J Cell Sci. 2009; 122:4452-4464. [PubMed: 19920073]

71. Dhakshinamoorthy S, Porter AG. Nitric oxide-induced transcriptional up-regulation of protective genes by Nrf2 via the antioxidant response element counteracts apoptosis of neuroblastoma cells. J Biol Chem. 2004; 279:20096-20107. [PubMed: 14985350]

72. Buckley BJ, Li S, Whorton AR. Keap1 modification and nuclear accumulation in response to Snitrosocysteine. Free Radic Biol Med. 2008; 44:692-698. [PubMed: 18062931]

73. Ashino T, Yamanaka R, Yamamoto M, Shimokawa H, Sekikawa K, Iwakura Y, Shioda S, Numazawa S, Yoshida T. Negative feedback regulation of lipopolysaccharide-induced inducible nitric oxide synthase gene expression by heme oxygenase- 1 induction in macrophages. Mol Immunol. 2008; 45:2106-2115. [PubMed: 18022235]

74. Wang P, Liu GH, Wu K, Qu J, Huang B, Zhang X, Zhou X, Gerace L, Chen C. Repression of classical nuclear export by S-nitrosylation of CRM1. J Cell Sci. 2009; 122:3772-3779. [PubMed: 19812309]

75. Forrester K, Ambs S, Lupold SE, Kapust RB, Spillare EA, Weinberg WC, Felley-Bosco E, Wang XW, Geller DA, Tzeng E, Billiar TR, Harris CC. Nitric oxide-induced p53 accumulation and regulation of inducible nitric oxide synthase expression by wild-type p53. Proc Natl Acad Sci U S A. 1996; 93:2442-2447. [PubMed: 8637893]

76. Hainaut P, Mann K. Zinc binding and redox control of p53 structure and function. Antioxid Redox Signal. 2001; 3:611-623. [PubMed: 11554448]

77. Rainwater R, Parks D, Anderson ME, Tegtmeyer P, Mann K. Role of cysteine residues in regulation of p53 function. Mol Cell Biol. 1995; 15:3892-3903. [PubMed: 7791795]

78. Schonhoff CM, Daou MC, Jones SN, Schiffer CA, Ross AH. Nitric oxide-mediated inhibition of Hdm2-p53 binding. Biochemistry. 2002; 41:13570-13574. [PubMed: 12427017]

79. Nakaya N, Lowe SW, Taya Y, Chenchik A, Enikolopov G. Specific pattern of p53 phosphorylation during nitric oxide-induced cell cycle arrest. Oncogene. 2000; 19:6369-6375. [PubMed: 11175352]

80. Ho YS, Wang YJ, Lin JK. Induction of p53 and p21/WAF1/CIP1 expression by nitric oxide and their association with apoptosis in human cancer cells. Mol Carcinog. 1996; 16:20-31. [PubMed: 8634091]

81. McLaughlin LM, Demple B. Nitric oxide-induced apoptosis in lymphoblastoid and fibroblast cells dependent on the phosphorylation and activation of p53. Cancer Res. 2005; 65:6097-6104. [PubMed: 16024610]

82. Park HS, Huh SH, Kim MS, Lee SH, Choi EJ. Nitric oxide negatively regulates c-Jun N-terminal kinase/stress-activated protein kinase by means of S-nitrosylation. Proc Natl Acad Sci U S A. 2000; 97:14382-14387. [PubMed: 11121042]

83. Pi X, Wu Y, Ferguson JE III, Portbury AL, Patterson C. SDF-1alpha stimulates JNK3 activity via eNOS-dependent nitrosylation of MKP7 to enhance endothelial migration. Proc Natl Acad Sci U S A. 2009; 106:5675-5680. [PubMed: 19307591]

84. van Dieck J, Teufel DP, Jaulent AM, Fernandez-Fernandez MR, Rutherford TJ, WyslouchCieszynska A, Fersht AR. Posttranslational modifications affect the interaction of S100 proteins with tumor suppressor p53. J Mol Biol. 2009; 394:922-930. [PubMed: 19819244]

85. Turner J, Crossley M. Mammalian Kruppel-like transcription factors: more than just a pretty finger. Trends Biochem Sci. 1999; 24:236-240. [PubMed: 10366853] 
86. Kroncke KD. Zinc finger proteins as molecular targets for nitric oxide-mediated gene regulation. Antioxid Redox Signal. 2001; 3:565-575. [PubMed: 11554445]

87. Berendji D, Kolb-Bachofen V, Zipfel PF, Skerka C, Carlberg C, Kroncke KD. Zinc finger transcription factors as molecular targets for nitric oxide-mediated immunosuppression: inhibition of IL-2 gene expression in murine lymphocytes. Mol Med. 1999; 5:721-730. [PubMed: 10656874]

88. Kroncke KD, Haase H, Beyersmann D, Kolb-Bachofen V, Hayer-Hartl MK. Nitric oxide inhibits the cochaperone activity of the RING finger-like protein DnaJ. Nitric Oxide. 2001; 5:289-295. [PubMed: 11485367]

89. Baldelli S, Aquilano K, Rotilio G, Ciriolo MR. Glutathione and copper, zinc superoxide dismutase are modulated by overexpression of neuronal nitric oxide synthase. Int J Biochem Cell Biol. 2008; 40:2660-2670. [PubMed: 18586551]

90. Baldelli S, Aquilano K, Rotilio G, Ciriolo MR. Neuronal nitric oxide synthase interacts with Sp1 through the PDZ domain inhibiting Sp1-mediated copper-zinc superoxide dismutase expression. Int J Biochem Cell Biol. 2011; 43:163-169. [PubMed: 21056687]

91. Zhuravliova E, Barbakadze T, Narmania N, Ramsden J, Mikeladze D. Inhibition of nitric oxide synthase and farnesyltransferase change the activities of several transcription factors. J Mol Neurosci. 2007; 31:281-287. [PubMed: 17726232]

92. Zhang J, Wang S, Wesley RA, Danner RL. Adjacent sequence controls the response polarity of nitric oxide-sensitive Sp factor binding sites. J Biol Chem. 2003; 278:29192-29200. [PubMed: 12759366]

93. Wang S, Wang W, Wesley RA, Danner RL. A Sp1 binding site of the tumor necrosis factor alpha promoter functions as a nitric oxide response element. J Biol Chem. 1999; 274:33190-33193. [PubMed: 10559188]

94. Beck K, Wu BJ, Ni J, Santiago FS, Malabanan KP, Li C, Wang Y, Khachigian LM, Stocker R. Interplay between heme oxygenase- 1 and the multi-functional transcription factor yin yang 1 in the inhibition of intimal hyperplasia. Circ Res. 2010; 107:1490-1497. [PubMed: 21030713]

95. Garban HJ, Bonavida B. Nitric oxide inhibits the transcription repressor Yin-Yang 1 binding activity at the silencer region of the Fas promoter: a pivotal role for nitric oxide in the upregulation of Fas gene expression in human tumor cells. J Immunol. 2001; 167:75-81. [PubMed: 11418634]

96. Hongo F, Garban H, Huerta-Yepez S, Vega M, Jazirehi AR, Mizutani Y, Miki T, Bonavida B. Inhibition of the transcription factor Yin Yang 1 activity by S-nitrosation. Biochem Biophys Res Commun. 2005; 336:692-701. [PubMed: 16143308]

97. Huerta-Yepez S, Vega M, Escoto-Chavez SE, Murdock B, Sakai T, Baritaki S, Bonavida B. Nitric oxide sensitizes tumor cells to TRAIL-induced apoptosis via inhibition of the DR5 transcription repressor Yin Yang 1. Nitric Oxide. 2009; 20:39-52. [PubMed: 18778787]

98. Aranda A, Pascual A. Nuclear hormone receptors and gene expression. Physiol Rev. 2001; 81:1269-1304. [PubMed: 11427696]

99. Galigniana MD, Piwien-Pilipuk G, Assreuy J. Inhibition of glucocorticoid receptor binding by nitric oxide. Mol Pharmacol. 1999; 55:317-323. [PubMed: 9927624]

100. Garban HJ, Marquez-Garban DC, Pietras RJ, Ignarro LJ. Rapid nitric oxide-mediated Snitrosylation of estrogen receptor: regulation of estrogen-dependent gene transcription. Proc Natl Acad Sci U S A. 2005; 102:2632-2636. [PubMed: 15699347]

101. Zhang HH, Feng L, Livnat I, Hoh JK, Shim JY, Liao WX, Chen DB. Estradiol-17beta stimulates specific receptor and endogenous nitric oxide-dependent dynamic endothelial protein Snitrosylation: analysis of endothelial nitrosyl-proteome. Endocrinology. 2010; 151:3874-3887. [PubMed: 20519370]

102. Lin J, Steenbergen C, Murphy E, Sun J. Estrogen receptor-beta activation results in Snitrosylation of proteins involved in cardioprotection. Circulation. 2009; 120:245-254. [PubMed: 19581491]

103. Sladek FM. Orphan receptor HNF-4 and liver-specific gene expression. Receptor. 1994; 4:64. [PubMed: 8038708] 
104. Jover R, Bort R, Gomez-Lechon MJ, Castell JV. Cytochrome P450 regulation by hepatocyte nuclear factor 4 in human hepatocytes: a study using adenovirus-mediated antisense targeting. Hepatology. 2001; 33:668-675. [PubMed: 11230748]

105. Hara H, Adachi T. Contribution of hepatocyte nuclear factor-4 to down-regulation of CYP2D6 gene expression by nitric oxide. Mol Pharmacol. 2002; 61:194-200. [PubMed: 11752221]

106. Boggaram V, Chandru H, Gottipati KR, Thakur V, Das A, Berhane K. Transcriptional regulation of SP-B gene expression by nitric oxide in H441 lung epithelial cells. Am J Physiol Lung Cell Mol Physiol. 2010; 299:L252-L262. [PubMed: 20418387]

107. Jagtap P, Szabo C. Poly(ADP-ribose) polymerase and the therapeutic effects of its inhibitors. Nat Rev Drug Discov. 2005; 4:421-440. [PubMed: 15864271]

108. Chang WJ, Alvarez-Gonzalez R. The sequence-specific DNA binding of NF-kappa B is reversibly regulated by the automodification reaction of poly (ADP-ribose) polymerase 1 . J Biol Chem. 2001; 276:47664-47670. [PubMed: 11577079]

109. Nakajima H, Nagaso H, Kakui N, Ishikawa M, Hiranuma T, Hoshiko S. Critical role of the automodification of poly(ADP-ribose) polymerase-1 in nuclear factor-kappaB-dependent gene expression in primary cultured mouse glial cells. J Biol Chem. 2004; 279:42774-42786. [PubMed: 15302869]

110. Dodon MD, Hamaia S, Martin J, Gazzolo L. Heterogeneous nuclear ribonucleoprotein A1 interferes with the binding of the human $\mathrm{T}$ cell leukemia virus type 1 rex regulatory protein to its response element. J Biol Chem. 2002; 277:18744-18752. [PubMed: 11893730]

111. Tauler J, Mulshine JL. Lung cancer and inflammation: interaction of chemokines and hnRNPs. Curr Opin Pharmacol. 2009; 9:384-388. [PubMed: 19570713]

112. Soderberg M, Raffalli-Mathieu F, Lang MA. Inflammation modulates the interaction of heterogeneous nuclear ribonucleoprotein (hnRNP) I/polypyrimidine tract binding protein and hnRNP L with the 3'untranslated region of the murine inducible nitric-oxide synthase mRNA. Mol Pharmacol. 2002; 62:423-431. [PubMed: 12130696]

113. Soderberg M, Raffalli-Mathieu F, Lang MA. Regulation of the murine inducible nitric oxide synthase gene by dexamethasone involves a heterogeneous nuclear ribonucleoprotein I (hnRNPI) dependent pathway. Mol Immunol. 2007; 44:3204-3210. [PubMed: 17379310]

114. Gao C, Mi Z, Guo H, Wei J, Wai PY, Kuo PC. A transcriptional repressor of osteopontin expression in the 4T1 murine breast cancer cell line. Biochem Biophys Res Commun. 2004; 321:1010-1016. [PubMed: 15358129]

115. Gao C, Guo H, Wei J, Mi Z, Wai P, Kuo PC. S-nitrosylation of heterogeneous nuclear ribonucleoprotein $\mathrm{A} / \mathrm{B}$ regulates osteopontin transcription in endotoxin-stimulated murine macrophages. J Biol Chem. 2004; 279:11236-11243. [PubMed: 14722087]

116. Gao C, Guo H, Mi Z, Wai PY, Kuo PC. Transcriptional regulatory functions of heterogeneous nuclear ribonucleoprotein- $\mathrm{U}$ and $-\mathrm{A} / \mathrm{B}$ in endotoxin-mediated macrophage expression of osteopontin. J Immunol. 2005; 175:523-530. [PubMed: 15972688]

117. Wagner EF, Nebreda AR. Signal integration by JNK and p38 MAPK pathways in cancer development. Nat Rev Cancer. 2009; 9:537-549. [PubMed: 19629069]

118. Dhanasekaran DN, Reddy EP. JNK signaling in apoptosis. Oncogene. 2008; 27:6245-6251. [PubMed: 18931691]

119. Pei DS, Song YJ, Yu HM, Hu WW, Du Y, Zhang GY. Exogenous nitric oxide negatively regulates c-Jun N-terminal kinase activation via inhibiting endogenous NO-induced Snitrosylation during cerebral ischemia and reperfusion in rat hippocampus. J Neurochem. 2008; 106:1952-1963. [PubMed: 18565207]

120. Park HS, Huh SH, Kim MS, Kim DY, Gwag BJ, Cho SG, Choi EJ. Neuronal nitric oxide synthase (nNOS) modulates the JNK1 activity through redox mechanism: a cGMP independent pathway. Biochem Biophys Res Commun. 2006; 346:408-414. [PubMed: 16764826]

121. Park HS, Mo JS, Choi EJ. Nitric oxide inhibits an interaction between JNK1 and c-Jun through nitrosylation. Biochem Biophys Res Commun. 2006; 351:281-286. [PubMed: 17054907]

122. Sumbayev VV. S-nitrosylation of thioredoxin mediates activation of apoptosis signal-regulating kinase 1. Arch Biochem Biophys. 2003; 415:133-136. [PubMed: 12801522] 
123. Park HS, Yu JW, Cho JH, Kim MS, Huh SH, Ryoo K, Choi EJ. Inhibition of apoptosis signalregulating kinase 1 by nitric oxide through a thiol redox mechanism. J Biol Chem. 2004; 279:7584-7590. [PubMed: 14668338]

124. McCubrey JA, Steelman LS, Abrams SL, Bertrand FE, Ludwig DE, Basecke J, Libra M, Stivala F, Milella M, Tafuri A, Lunghi P, Bonati A, Martelli AM. Targeting survival cascades induced by activation of Ras/Raf/MEK/ERK, PI3K/PTEN/Akt/mTOR and Jak/STAT pathways for effective leukemia therapy. Leukemia. 2008; 22:708-722. [PubMed: 18337766]

125. Lander HM, Ogiste JS, Pearce SF, Levi R, Novogrodsky A. Nitric oxide-stimulated guanine nucleotide exchange on p21ras. J Biol Chem. 1995; 270:7017-7020. [PubMed: 7706235]

126. Lin YF, Raab-Graham K, Jan YN, Jan LY. NO stimulation of ATP-sensitive potassium channels: involvement of Ras/mitogen-activated protein kinase pathway and contribution to neuroprotection. Proc Natl Acad Sci U S A. 2004; 101:7799-7804. [PubMed: 15136749]

127. An HJ, Maeng O, Kang KH, Lee JO, Kim YS, Paik SG, Lee H. Activation of Ras up-regulates pro-apoptotic BNIP3 in nitric oxide-induced cell death. J Biol Chem. 2006; 281:33939-33948. [PubMed: 16954213]

128. Lim KH, Ancrile BB, Kashatus DF, Counter CM. Tumour maintenance is mediated by eNOS. Nature. 2008; 452:646-649. [PubMed: 18344980]

129. Ibiza S, Perez-Rodriguez A, Ortega A, Martinez-Ruiz A, Barreiro O, Garcia-Dominguez CA, Victor VM, Esplugues JV, Rojas JM, Sanchez-Madrid F, Serrador JM. Endothelial nitric oxide synthase regulates N-Ras activation on the Golgi complex of antigen-stimulated T cells. Proc Natl Acad Sci U S A. 2008; 105:10507-10512. [PubMed: 18641128]

130. Yasukawa T, Tokunaga E, Ota H, Sugita H, Martyn JA, Kaneki M. S-nitrosylation-dependent inactivation of Akt/protein kinase B in insulin resistance. J Biol Chem. 2005; 280:7511-7518. [PubMed: 15632167]

131. Wu M, Katta A, Gadde MK, Liu H, Kakarla SK, Fannin J, Paturi S, Arvapalli RK, Rice KM, Wang Y, Blough ER. Aging-associated dysfunction of Akt/protein kinase B: S-nitrosylation and acetaminophen intervention. PLoS One. 2009; 4:e6430. [PubMed: 19641606]

132. Estrada C, Gomez C, Martin-Nieto J, De Frutos T, Jimenez A, Villalobo A. Nitric oxide reversibly inhibits the epidermal growth factor receptor tyrosine kinase. Biochem J. 1997; 326(Pt 2):369-376. [PubMed: 9291107]

133. Murillo-Carretero M, Torroglosa A, Castro C, Villalobo A, Estrada C. S-Nitrosylation of the epidermal growth factor receptor: a regulatory mechanism of receptor tyrosine kinase activity. Free Radic Biol Med. 2009; 46:471-479. [PubMed: 19056486]

134. Li S, Whorton AR. Regulation of protein tyrosine phosphatase 1B in intact cells by Snitrosothiols. Arch Biochem Biophys. 2003; 410:269-279. [PubMed: 12573287]

135. Barrett DM, Black SM, Todor H, Schmidt-Ullrich RK, Dawson KS, Mikkelsen RB. Inhibition of protein-tyrosine phosphatases by mild oxidative stresses is dependent on S-nitrosylation. J Biol Chem. 2005; 280:14453-14461. [PubMed: 15684422]

136. Chen YY, Chu HM, Pan KT, Teng CH, Wang DL, Wang AH, Khoo KH, Meng TC. Cysteine Snitrosylation protects protein-tyrosine phosphatase 1B against oxidation-induced permanent inactivation. J Biol Chem. 2008; 283:35265-35272. [PubMed: 18840608]

137. Lim S, Clement MV. Phosphorylation of the survival kinase Akt by superoxide is dependent on an ascorbate-reversible oxidation of PTEN. Free Radic Biol Med. 2007; 42:1178-1192. [PubMed: 17382199]

138. Pei DS, Sun YF, Song YJ. S-nitrosylation of PTEN Invovled in ischemic brain injury in rat hippocampal CA1 region. Neurochem Res. 2009; 34:1507-1512. [PubMed: 19266280]

139. Kwak YD, Ma T, Diao S, Zhang X, Chen Y, Hsu J, Lipton SA, Masliah E, Xu H, Liao FF. NO signaling and S-nitrosylation regulate PTEN inhibition in neurodegeneration. Mol Neurodegener. 2010; 5:49. [PubMed: 21067594]

140. Molina y Vedia L, McDonald B, Reep B, Brune B, Di Silvio M, Billiar TR, Lapetina EG. Nitric oxide-induced S-nitrosylation of glyceraldehyde-3-phosphate dehydrogenase inhibits enzymatic activity and increases endogenous ADP-ribosylation. J Biol Chem. 1992; 267:24929-24932. [PubMed: 1281150] 
141. Hara MR, Agrawal N, Kim SF, Cascio MB, Fujimuro M, Ozeki Y, Takahashi M, Cheah JH, Tankou SK, Hester LD, Ferris CD, Hayward SD, Snyder SH, Sawa A. S-nitrosylated GAPDH initiates apoptotic cell death by nuclear translocation following Siah1 binding. Nat Cell Biol. 2005; 7:665-674. [PubMed: 15951807]

142. Sen N, Hara MR, Kornberg MD, Cascio MB, Bae BI, Shahani N, Thomas B, Dawson TM, Dawson VL, Snyder SH, Sawa A. Nitric oxide-induced nuclear GAPDH activates p300/CBP and mediates apoptosis. Nat Cell Biol. 2008; 10:866-873. [PubMed: 18552833]

143. Kornberg MD, Sen N, Hara MR, Juluri KR, Nguyen JV, Snowman AM, Law L, Hester LD, Snyder SH. GAPDH mediates nitrosylation of nuclear proteins. Nat Cell Biol. 2010; 12:10941100. [PubMed: 20972425]

144. Fulton D, Babbitt R, Zoellner S, Fontana J, Acevedo L, McCabe TJ, Iwakiri Y, Sessa WC. Targeting of endothelial nitric-oxide synthase to the cytoplasmic face of the Golgi complex or plasma membrane regulates Akt- versus calcium-dependent mechanisms for nitric oxide release. J Biol Chem. 2004; 279:30349-30357. [PubMed: 15136572]

145. Iwakiri Y, Satoh A, Chatterjee S, Toomre DK, Chalouni CM, Fulton D, Groszmann RJ, Shah VH, Sessa WC. Nitric oxide synthase generates nitric oxide locally to regulate compartmentalized protein S-nitrosylation and protein trafficking. Proc Natl Acad Sci U S A. 2006; 103:1977719782. [PubMed: 17170139]

146. Giordano A, Tonello C, Bulbarelli A, Cozzi V, Cinti S, Carruba MO, Nisoli E. Evidence for a functional nitric oxide synthase system in brown adipocyte nucleus. FEBS Lett. 2002; 514:135140. [PubMed: 11943139]

147. Saini R, Patel S, Saluja R, Sahasrabuddhe AA, Singh MP, Habib S, Bajpai VK, Dikshit M. Nitric oxide synthase localization in the rat neutrophils: immunocytochemical, molecular, and biochemical studies. J Leukoc Biol. 2006; 79:519-528. [PubMed: 16387842]

148. Abdelmagid SA, Rickard JA, McDonald WJ, Thomas LN, Too CK. CAT-1-mediated arginine uptake and regulation of nitric oxide synthases for the survival of human breast cancer cell lines. J Cell Biochem. 2011; 112:1084-1092. [PubMed: 21308737]

149. Gobeil F Jr, Zhu T, Brault S, Geha A, Vazquez-Tello A, Fortier A, Barbaz D, Checchin D, Hou X, Nader M, Bkaily G, Gratton JP, Heveker N, Ribeiroda-Silva A, Peri K, Bard H, Chorvatova A, D’Orleans-Juste P, Goetzl EJ, Chemtob S. Nitric oxide signaling via nuclearized endothelial nitric-oxide synthase modulates expression of the immediate early genes iNOS and mPGES-1. J Biol Chem. 2006; 281:16058-16067. [PubMed: 16574649]

150. Connelly L, Madhani M, Hobbs AJ. Resistance to endotoxic shock in endothelial nitric-oxide synthase (eNOS) knock-out mice: a pro-inflammatory role for eNOS-derived no in vivo. J Biol Chem. 2005; 280:10040-10046. [PubMed: 15647265]

151. Grasselli A, Nanni S, Colussi C, Aiello A, Benvenuti V, Ragone G, Moretti F, Sacchi A, Bacchetti S, Gaetano C, Capogrossi MC, Pontecorvi A, Farsetti A. Estrogen receptor-alpha and endothelial nitric oxide synthase nuclear complex regulates transcription of human telomerase. Circ Res. 2008; 103:34-42. [PubMed: 18519947]

152. Yu Z, Zhang W, Kone BC. Histone deacetylases augment cytokine induction of the iNOS gene. J Am Soc Nephrol. 2002; 13:2009-2017. [PubMed: 12138131]

153. Rossig L, Li H, Fisslthaler B, Urbich C, Fleming I, Forstermann U, Zeiher AM, Dimmeler S. Inhibitors of histone deacetylation downregulate the expression of endothelial nitric oxide synthase and compromise endothelial cell function in vasorelaxation and angiogenesis. Circ Res. 2002; 91:837-844. [PubMed: 12411399]

154. Li Y, Zhao Y, Li G, Wang J, Li T, Li W, Lu J. Regulation of neuronal nitric oxide synthase exon 1f gene expression by nuclear factor-kappaB acetylation in human neuroblastoma cells. $\mathrm{J}$ Neurochem. 2007; 101:1194-1204. [PubMed: 17250678]

155. Hassa PO, Haenni SS, Buerki C, Meier NI, Lane WS, Owen H, Gersbach M, Imhof R, Hottiger MO. Acetylation of poly(ADP-ribose) polymerase-1 by p300/CREB-binding protein regulates coactivation of NF-kappaB-dependent transcription. J Biol Chem. 2005; 280:40450-40464. [PubMed: 16204234]

156. Nott A, Watson PM, Robinson JD, Crepaldi L, Riccio A. S-Nitrosylation of histone deacetylase 2 induces chromatin remodelling in neurons. Nature. 2008; 455:411-415. [PubMed: 18754010] 
157. Watson PM, Riccio A. Nitric oxide and histone deacetylases: a new relationship between old molecules. Commun Integr Biol. 2009; 2:11-13. [PubMed: 19704855]

158. Colussi C, Mozzetta C, Gurtner A, Illi B, Rosati J, Straino S, Ragone G, Pescatori M, Zaccagnini G, Antonini A, Minetti G, Martelli F, Piaggio G, Gallinari P, Steinkuhler C, Clementi E, Dell'Aversana C, Altucci L, Mai A, Capogrossi MC, Puri PL, Gaetano C. HDAC2 blockade by nitric oxide and histone deacetylase inhibitors reveals a common target in Duchenne muscular dystrophy treatment. Proc Natl Acad Sci U S A. 2008; 105:19183-19187. [PubMed: 19047631]

159. Pakala SB, Bui-Nguyen TM, Reddy SD, Li DQ, Peng S, Rayala SK, Behringer RR, Kumar R. Regulation of NF-kappaB circuitry by a component of the nucleosome remodeling and deacetylase complex controls inflammatory response homeostasis. J Biol Chem. 2010; 285:23590-23597. [PubMed: 20519513]

160. Martin M, Potente M, Janssens V, Vertommen D, Twizere JC, Rider MH, Goris J, Dimmeler S, Kettmann R, Dequiedt F. Protein phosphatase 2A controls the activity of histone deacetylase 7 during T cell apoptosis and angiogenesis. Proc Natl Acad Sci U S A. 2008; 105:4727-4732. [PubMed: 18339811]

161. Malik M, Shukla A, Amin P, Niedelman W, Lee J, Jividen K, Phang JM, Ding J, Suh KS, Curmi PM, Yuspa SH. S-nitrosylation regulates nuclear translocation of chloride intracellular channel protein CLIC4. J Biol Chem. 2010; 285:23818-23828. [PubMed: 20504765]

162. Ckless K, Reynaert NL, Taatjes DJ, Lounsbury KM, van der Vliet A, Janssen-Heininger Y. In situ detection and visualization of S-nitrosylated proteins following chemical derivatization: identification of Ran GTPase as a target for S-nitrosylation. Nitric Oxide. 2004; 11:216-227. [PubMed: 15566968]

163. Lam YW, Yuan Y, Isaac J, Babu CV, Meller J, Ho SM. Comprehensive identification and modified-site mapping of S-nitrosylated targets in prostate epithelial cells. PLoS One. 2010; 5:e9075. [PubMed: 20140087]

164. Schroeder P, Popp R, Wiegand B, Altschmied J, Haendeler J. Nuclear redox-signaling is essential for apoptosis inhibition in endothelial cells-important role for nuclear thioredoxin-1. Arterioscler Thromb Vasc Biol. 2007; 27:2325-2331. [PubMed: 17823364]

165. Qu J, Liu GH, Huang B, Chen C. Nitric oxide controls nuclear export of APE1/Ref-1 through Snitrosation of cysteines 93 and 310. Nucleic Acids Res. 2007; 35:2522-2532. [PubMed: 17403694]

166. Ando K, Hirao S, Kabe Y, Ogura Y, Sato I, Yamaguchi Y, Wada T, Handa H. A new APE1/ Ref-1-dependent pathway leading to reduction of NF-kappaB and AP-1, and activation of their DNA-binding activity. Nucleic Acids Res. 2008; 36:4327-4336. [PubMed: 18586825]

167. Martinez-Moreno M, Martinez-Ruiz A, Alvarez-Barrientos A, Gavilanes F, Lamas S, RodriguezCrespo I. Nitric oxide down-regulates caveolin-3 levels through the interaction with myogenin, its transcription factor. J Biol Chem. 2007; 282:23044-23054. [PubMed: 17519233] 


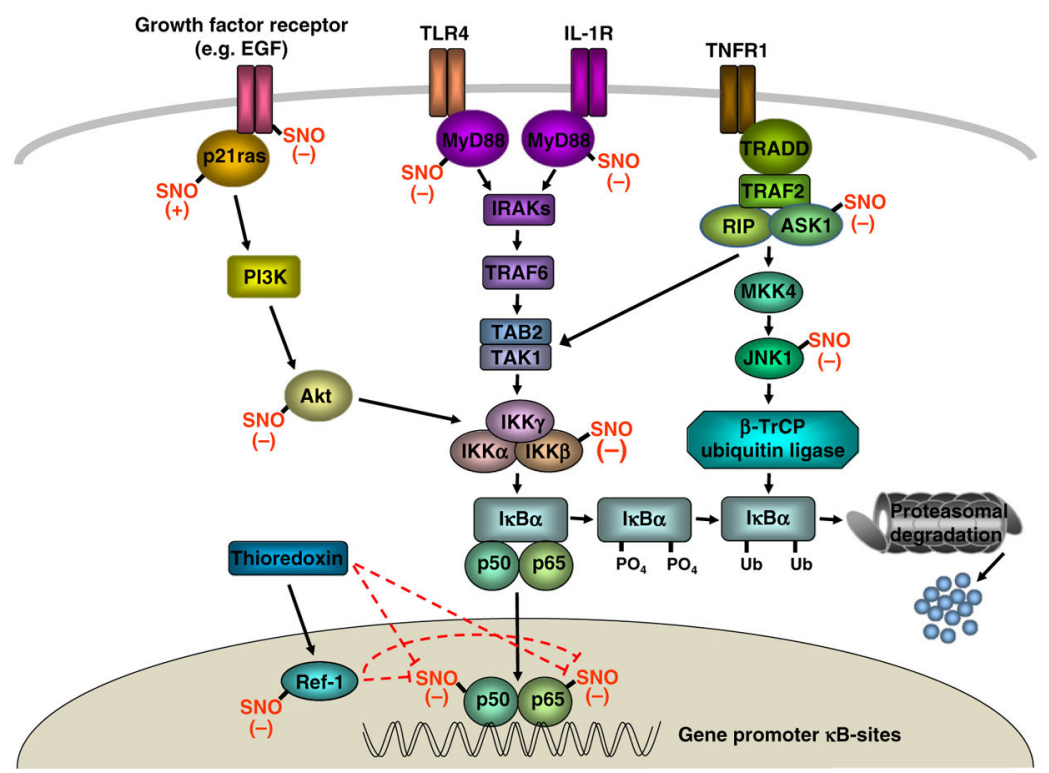

Fig. 1.

S-nitrosylation in NF- $\kappa$ B signaling. Engagement of cell surface receptors [TNFa (TNFR1), IL-1 (IL-1R), TLR-4, growth factor receptor] leads to the recruitment of receptor-associated proteins, several of which, p21ras, epidermal growth factor (EGF) tyrosine kinase, and MyD88, are regulated by S-nitrosylation. TNFR1 also activates the JNK kinase pathway which can enhance $\mathrm{NF}-\kappa \mathrm{B}$ signaling via the effects of the E3 ubiquitin ligase SCF- $\beta$-TrCP and I $\kappa \mathrm{Ba}$ proteasomal degradation. S-nitrosylation of two JNK pathway proteins, apoptosis signaling kinase 1 (ASK1) and JNK1, inhibit SCF- $\beta$-TrCP activation. Phosphorylation of $\mathrm{I} \kappa \mathrm{Ba}$, which targets it for ubiquitin-mediated proteasomal degradation, is inhibited by SNO modification of the I $\kappa \mathrm{Ba}$ kinase $\beta$ (IKK $\beta$ ) subunit or the ras pathway protein Akt. DNA binding of the NF- $\kappa$ B activating heterodimer (p50-p65) is inhibited by S-nitrosylation of either subunit. Thioredoxin can denitrosylate NF- $\kappa B$ p50-p65 directly or indirectly via activation of Ref-1 in the nucleus. S-nitrosylation, in turn, inhibits the activity of thioredoxin and Ref-1. 


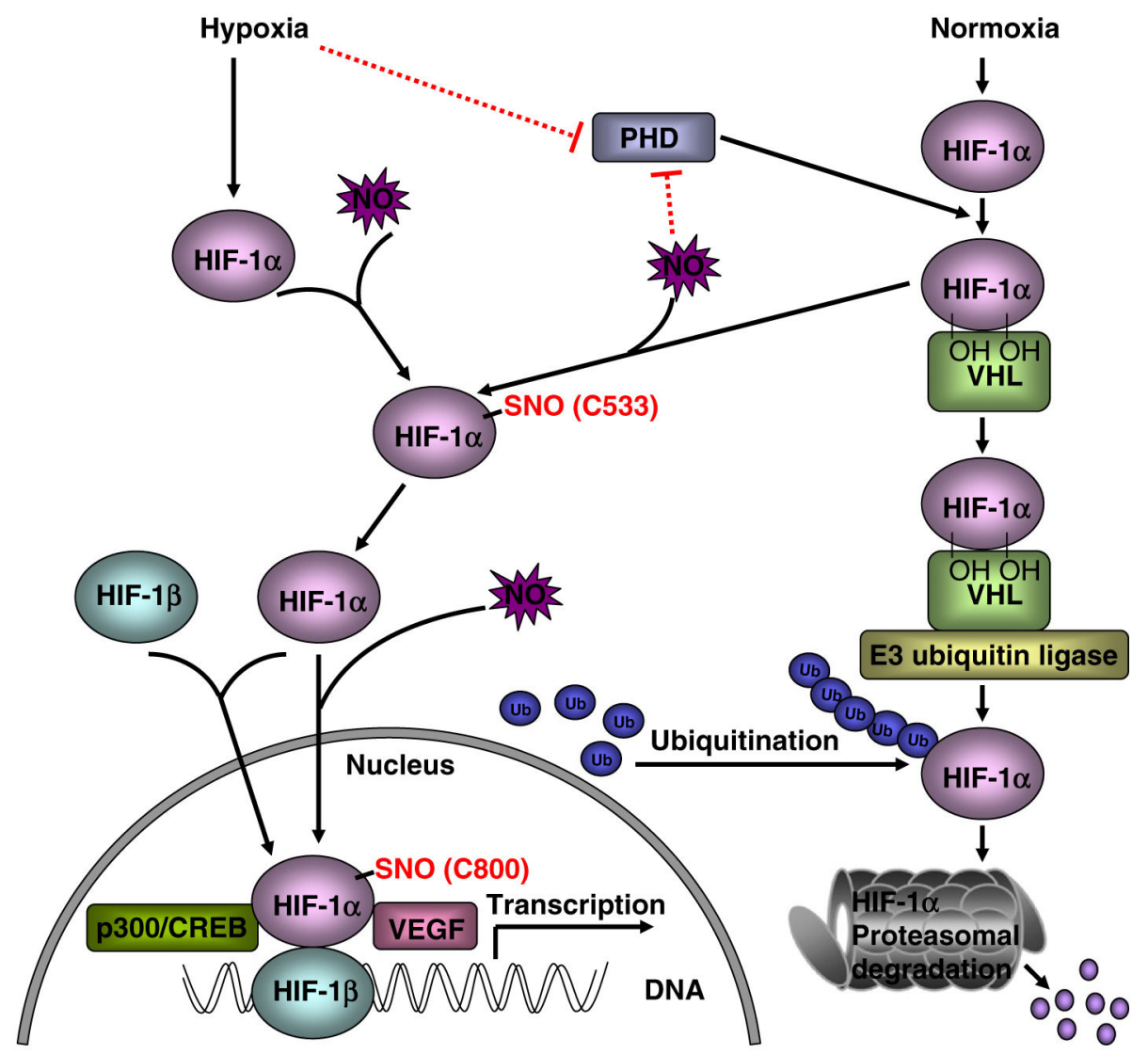

Fig. 2.

S-nitrosylation in HIF-1 signaling. NO inhibits proline hydroxylases (PHD) under normoxic conditions. S-nitrosylation of HIF-1a at cysteine-533 (C533) interferes with binding to the von Hippel Lindau (VHL) protein preventing its ubiquitination and proteasomal degradation. HIF-1a interacts with HIF-1 $\beta$ and the complex translocates to the nucleus to activate genes such as VEGF. HIF-1a also undergoes S-nitrosylation at cysteine-800 (C800) facilitating binding of the transcriptional co-factor p300/CREBwhich also increases HIF-1dependent transcription. 
Table 1

List of transcription factors directly regulated by S-nitrosylation.

\begin{tabular}{|c|c|c|c|}
\hline Transcription factor & Location of modified cysteine & Effect & References \\
\hline$N F-\kappa B$ p50 & DNA binding domain & Inhibition of DNA binding & {$[18,48]$} \\
\hline$N F-\kappa B$ p 65 & DNA binding domain & Inhibition of DNA binding & {$[34,49]$} \\
\hline AP-1 c-Jun & DNA binding domain & Inhibition of DNA binding & {$[66-68]$} \\
\hline AP-1 c-Fos & DNA binding domain & Inhibition of DNA binding & {$[66,67]$} \\
\hline HIF-1a (C533) & Oxygen-dependent degradation domain & Protein stabilization & {$[57]$} \\
\hline HIF-1a (C800) & Transactivation Domain & $\begin{array}{l}\text { Enhanced binding of CREB transactivation co- } \\
\text { factor }\end{array}$ & {$[61,62]$} \\
\hline Sp1 & Zinc finger DNA binding domain (proposed) & Inhibition of DNA binding & {$[52,90,92,93]$} \\
\hline EGR-1 & Zinc finger DNA binding domain (proposed) & Inhibition of DNA binding & {$[52,87,88]$} \\
\hline Yin Yang 1 & Zinc finger DNA binding domain (proposed) & Inhibition of DNA binding & {$[95-97]$} \\
\hline Hepatocyte nuclear factor-4 & Zinc finger DNA binding domain (proposed) & Inhibition of DNA binding & {$[104,105]$} \\
\hline Estrogen receptor & Zinc finger DNA binding domain (proposed) & Inhibition of DNA binding & {$[100-102]$} \\
\hline PARP-1 & Zinc finger DNA binding domain (proposed) & Inhibition of DNA binding & {$[33,109]$} \\
\hline Myogenin & DNA binding domain (proposed) & Inhibition of DNA binding & [167] \\
\hline
\end{tabular}

